\title{
The importance of beech forests in the preservation of valuable species of the flora of Dagestan
}

\author{
Khabagin Aliev* \\ Mountain Botanical Garden of DFRC RAS, Makhachkala, Russia
}

\begin{abstract}
Forests dominated by Fagus orientalis Lipsky play the greatest role in maintaining the ecological balance in the Caucasian Isthmus. Beech, having a high edificatory effect, contributes to the formation of a unique composition of the flora. In Dagestan, beech forests are located at the edge of their range in the relatively arid conditions of the Eastern Caucasus. The studied forests are rich in Hyrcanic and Colchian relict and endemic elements. In this regard, it became necessary to identify the most valuable areas of beech forests and take urgent measures to preserve them. The work is devoted to the study of the importance of beech forests in the preservation of 88 species of relict, endemic and protected species of the flora of Dagestan. Based on the data of geobotanical descriptions of 73 test plots, with a total area of $45625 \mathrm{~m}^{2}$, an environmental assessment of the value of phytocenoses is given. In total, 19 associations have been identified in the beech forests of Dagestan. Disjunctive growth of some species was noted in the beech forests of the republic. The most valuable are beech forests growing in the refugia of Low and Foothill Dagestan, where there is a reduction in areas due to negative anthropogenic impact. In highmountainous beech forests, no reduction in areas is observed, and forest fires, which have been observed more and more often in recent years, remain the main limiting factor. The data on the inclusion of the most valuable areas of beech forests in the protected areas, and for some areas already included in the protected areas, recommendations are given on the introduction of a special regime of use in them.
\end{abstract}

\section{Introduction}

Currently, for the protection of rare species of flora at the regional level, the most optimal is the preservation of plant communities where the species grow in natural conditions. At the same time, the role of plant communities is determined not only by their value as sources of plant resources and "carriers" of rare species, but also by the fact that they determine the distribution of heterotrophic biota and, accordingly, the nature of ecosystems [1].

Fagus orientalis Lipsky is one of 11 species of the relict genus of the Tertiary period, the modern range of which covers Southeast Europe, the Eastern Mediterranean and Southwestern Asia within Turkey, Syria and Northern Iran [2].

The forests formed by $F$. orientalis perform colossal functions aimed at maintaining ecological balance not only in Dagestan, but throughout the entire Caucasian ecoregion. In addition, having a high edificatory effect, beech contributes to the formation of a unique composition of flora in forest phytocenoses with its dominance. Beech forests are distinguished by their special dynamism, directly related to the climatic, edaphic and other features of a particular region and the intensified denudation processes in them. In this regard, the dysfunction of one of the components in the biogeocenosis with the dominance of the eastern beech contributes to changes in the historically established processes of mutual influence between the components [3].

In Dagestan, the main tracts of beech forests are concentrated in the Foothill physical-geographical region, growing here in a discontinuous strip at an altitude of $500-1800 \mathrm{~m}$ above sea level (Fig. 1). Isolated by the arid Innermountain physicalgeographical region of Dagestan, beech forests grow in small areas among mixed pine and birch forests in the High- mountain region at an altitude of 1600-2000 m above sea level [4]. Relatively recently, we found insignificant areas with the dominance of Fagus orientalis in the Samur liana forest at an altitude of 10 $20 \mathrm{~m}$ above sea level [5].

Until recently, there were disagreements on the issue of isolated growth and settlement in the postglacial period of the beech forests of Foothill and Highmountain Dagestan. So, I.I. Tumadzhanov has been dealing with the issues of florogenesis of the beech forests of Dagestan for more than three decades. He argued that the beech forests of the highlands are not dying relics of the Tertiary forest flora, as N.I. Kuznetsov, on the contrary, penetrated into the border

*Corresponding author: alievxu@mail.ru 
area of Dagestan from Kakheti only in the post-glacial period and now continue to penetrate and displace the dominant pine and birch forests [6-8].

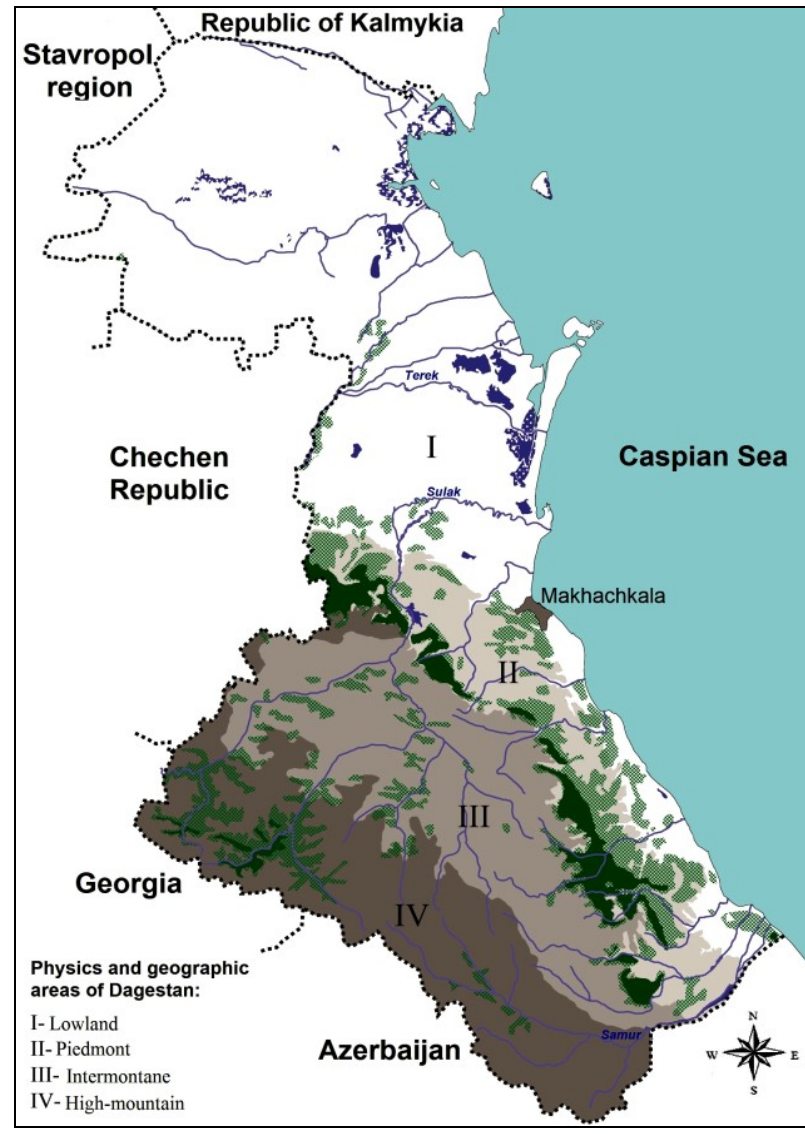

Fig. 1. Schematic map of physical-geographical regions and forested territory of the Republic of Dagestan (the borders of beech forests are marked in dark green)

In contrast, P.L. Lvov in his works points out that the beech forests of High-mountain Dagestan survived the Ice Age in the Bezhta and Shauri depressions, and did not penetrate here from Kakheti in the post-glacial time. In favor of his views, Lvov cites data on the geographical distribution and floristic composition of isolated areas of beech forests in Dagestan and adjacent regions $[9,10]$. The answer to this question was provided by our population genetic studies of 20 populations of Fagus orientalis from the territory of the Crimea and the Caucasus. The samples from the populations of High Mountain Dagestan and from the border regions from Eastern Georgia - Lagodekhi turned out to be genetically close, which speaks in favor of the views of I.I. Tumadzhanov on the florogenesis of beech trees in Dagestan [11].

Beech forests perform the functions of water protection, sanitary protection, erosion control, climate control and maintaining the ecological balance in the specified region, which are not appreciated in due measure. Growing at the edge of its range in the relatively arid conditions of the Eastern Caucasus, the studied beech forests are important by the growth of a large number of Hyrcanian and Colchian relict and endemic elements, rare and protected species in them. In addition, on the territory of the Republic of Dagestan and the Russian Federation, some of the species growing in beech forests have a disjunctive range. In this regard, there is a need to identify the most valuable areas of beech forests, and take urgent measures to preserve them, and, if necessary, give them the status of protected areas and maintain a special regime of use. In addition, for the region as a whole, there is still no complete information on the most valuable plant communities, and the necessary measures for their protection have not been organized.

\section{Materials and methods}

In this work, to identify valuable plant communities, a system of criteria for determining the nature conservation significance of associations was used [1]. The source for solving this problem was the data of geobotanical descriptions of 73 test plots, the description of which was carried out in the beech forests of the Lowland, Piedmont and High-mountain physicalgeographical regions of Dagestan. The geobotanical description on the sample plots was carried out according to generally accepted modern methods, and the ecological-phytocenotic approach was used to process the data obtained [12]. In addition, taking into account the specific features of the seasonal dynamics of the ground cover of beech forests during the growing season, the collection of data on the floristic composition on the sample plots was carried out in early spring, summer, and autumn. From a methodological point of view, the need for such an approach for the classification of broad-leaved forests in Dagestan is explained by the high role of early spring species (ephemeroids) in the formation of the ground cover in the spring. Based on the results of tabular processing of geobotanical data, we have compiled a classification of the beech forests of Dagestan, which include 19 associations that are part of the formation of the Fageta orientalis formation. Of these, 12 associations are typical for the Lowland and Piedmont zone, and 7 for the High-mountain zone [13].

In connection with the new data on finds in the beech forests of Dagestan and the reprint of the Red Data Book of the Republic of Dagestan [14], changes were made to the list of relict, endemic and protected species of higher vascular plants growing in the studied areas of the beech forests of Dagestan, compiled by us earlier [13] on based on literature data and own research [14-18].

\section{Results}

In the 19 identified associations of beech forests of Dagestan, 88 valuable species grow (Table 1). It can be seen from the data in the table that some protected species from this list are both endemics and relics, which indicates the natural-historical and chorological reasons for their rarity. In total, 33 species are included in the Red Data Book of Dagestan. Among them are 4 species of trees, 3 shrubs, 3 lianas, 23 perennial herbaceous species, of which 8 species belong to spring and autumn 
ephemeroids: Allium paradoxum, Anemone caucasica, Colchicum speciosum, Crocus speciosus, Fritillaria lagodechiana, Galanthus angustifolius, Galanthus lagodechianus, Ophrys oestrifera. Most of them are included in the Red Data Book of the Russian Federation and are endemic to the Eastern and Greater Caucasus.

Table 1. List of rare and protected, endemic and relict flora species of higher vascular plants growing in the 73 trial plots of beech forests of the Republic of Dagestan (with addition from Kh.U. Aliev [13])

\begin{tabular}{|c|c|c|c|c|}
\hline \multirow[t]{2}{*}{ Species } & \multicolumn{4}{|c|}{$\begin{array}{c}\text { Conservation } \\
\text { value } \\
\text { of the species }\end{array}$} \\
\hline & $\mathbf{A}$ & B & C & D \\
\hline Acer hyrcanum Fisch. et C.A. Mey. & & + & & + \\
\hline Acer laetum C. A. Mey. & & & + & + \\
\hline Aconitum nasutum Fisch. ex Reichenb. & & & + & \\
\hline Aconitum orientale Mill. & & & & + \\
\hline Actaea spicata L. & & & & + \\
\hline Allium paradoxum (M. Bieb.) G. Don & + & + & & + \\
\hline Alnus barbata C. A. Mey. & & & + & + \\
\hline Anemone caucasica Willd. ex Rupr. & & + & + & \\
\hline Anemone fasciculata L. & & & + & \\
\hline Arum consobrinum Schott & & & + & \\
\hline Asplenium adiantum-nigrum L. & + & + & & \\
\hline Astrantia maxima Pall. & & & + & \\
\hline Atropa caucasica Kreyer & + & + & + & \\
\hline Betula raddeana Trautv. & + & + & + & + \\
\hline Betula litwinowii Doluch. & & & + & + \\
\hline $\begin{array}{l}\text { Calycocorsus tuberosus (Fisch. et C.A. Mey.) } \\
\text { Rausch. }\end{array}$ & & & + & \\
\hline Campanula hohenackeri Fisch. et C.A. Mey. & & & + & \\
\hline Cephalanthera damasonium (Mill.) Druce & + & + & & \\
\hline Cardamine quinquifolia (M. Bieb.) Schmalh. & & & & + \\
\hline Cephalanthera longifolia (L.) Fritsch & + & + & & + \\
\hline Cephalanthera rubra (L.) Rich. & + & + & & + \\
\hline Cerastium holosteum Fisch. ex Hornem & & & + & \\
\hline Circaea lutetiana L. & & & & + \\
\hline Clematis vitalba L. & & + & & + \\
\hline Colchicum speciosum Steven & + & + & & \\
\hline Corylus avellana L. & & & & + \\
\hline Corylus colurna L. & + & + & & + \\
\hline Crocus speciosus M. Bieb. & + & + & & \\
\hline Dactylorhiza euxina (Nevski) Czerep. & & & + & \\
\hline $\begin{array}{l}\text { Dactylorhiza urvilleana (Steud.) H. Baumann } \\
\text { et Kuenkele }\end{array}$ & + & + & & \\
\hline Daphne glomerata Lam. & & & + & \\
\hline Doronicum macrophyllum Fisch. & & & + & \\
\hline Dryopteris filix-mas (L.) Schott & & & & + \\
\hline Epipactis condensata Bois. ex D.P. Young & & + & & \\
\hline Epipogium aphyllum Sw. & + & + & & \\
\hline Euphorbia macroceras Fisch. Et C.A. Mey. & & & + & \\
\hline Fagus orientalis Lipsky & & & & + \\
\hline Fritillaria lagodechiana Kharkev. & + & + & + & \\
\hline Galanthus angustifolius Koss & + & + & + & \\
\hline Galanthus lagodechianus Kem.-Nath. & + & + & + & \\
\hline Galega orientalis Lam. & & & + & \\
\hline Galium valantioides M. Bieb. & & & + & \\
\hline Geranium robertianum L. & & & & + \\
\hline Hedera pastuchovii Woronow & + & + & + & + \\
\hline Heracleum sommieri Manden. & & & + & \\
\hline Ilex hyrcana Pojark. & & + & & + \\
\hline Impatiens noli-tangere L. & & & & + \\
\hline
\end{tabular}

\begin{tabular}{|l|c|c|c|c|}
\hline Lathraea squamaria L. & & & + & \\
\hline Lilium monadelphum M. Bieb. & & & & \\
\hline Limodorum abortivum (L.) Sw. & + & + & & \\
\hline Ophrys oestrifera M. Bieb. & + & + & & + \\
\hline Orchis mascula (L.) L. & + & + & & \\
\hline Orchis purpurea Huds. & + & + & & \\
\hline Orobanche gamosepala Reut. & & & + & \\
\hline Oxalis acetosella L. & & & & + \\
\hline $\begin{array}{l}\text { Pachyphragma macrophyllum (Hoffm.) N. } \\
\text { Busch. }\end{array}$ & & & + & + \\
\hline Paris incompleta M. Bieb. & & & + & + \\
\hline Polygonatum glaberrimum K. Koch & & & + & \\
\hline Polygonatum verticillatum (L.) All. & & & & + \\
\hline Populus tremula L. & & & & + \\
\hline Polypodium vulgare L. & & & & + \\
\hline Pyrola rotundifolia L. & & & & + \\
\hline Primula macrocalyx Bunge & & & & + \\
\hline Pyrus caucasica Fed. & & & + & \\
\hline Phyllitis scolopendrium (L.) Newman & & & & + \\
\hline $\begin{array}{l}\text { Quercus macranthera Fisch. Et C. A. Mey. ex } \\
\text { Hohen. }\end{array}$ & & & & + \\
\hline $\begin{array}{l}\text { Quercus petraea subsp. Iberica (Steven) } \\
\text { Krassiln. }\end{array}$ & & & + & \\
\hline Rhododendron caucasicum Pall. & & & + & + \\
\hline Rhododendron luteum Sweet & & & & + \\
\hline Ribes caucasicum M. Bieb. & & & & + \\
\hline Rosa oxyodon Boiss. & & & + & \\
\hline Rubus caucasicus Focke & & & + & \\
\hline Salix caprea L. & & & + & \\
\hline Sanicula europaea L. & & & & + \\
\hline Scrophularia hyrcana Grossh. & & & + \\
\hline Sedum oppositifolium Sims & & + & + & + \\
\hline Senecio rhombifolius (Willd.) Sch. Bip. & & + & & + \\
\hline Smilax excelsa L. & + & + & & + \\
\hline Sorbus caucasica Zinserl. & & + & + \\
\hline Steveniella satyrioides (Spreng.) Schltr. & & + & + \\
\hline Symphytum asperum Lepech. & & & + \\
\hline Taxus baccata L. & & & + \\
\hline Tilia begoniifolia Steven & & & + \\
\hline Vaccinium arctostaphylos L. & & & + \\
\hline Vaccinium myrtillus L. & & & \\
\hline Valeriana tiliifolia Troitzky & & & \\
\hline Veronica crista-galli Steven & & & \\
\hline Woodsia fragilis (Trev.) T. Moore & & & \\
\hline A species listed ine Red Book & . & & \\
\hline
\end{tabular}

Woodsia fragilis (Trev.) T. Moore

A - species listed in the Red Book of the Russian Federation, B - species listed in the Red Book of the Republic of Dagestan, $\mathrm{C}$ - endemics, D - relicts.

The Red Book of the Russian Federation includes 23 species. Among the woody species, it is necessary to note the growth of such rare trees as Taxus baccata, Corylus colurna and Betula raddeana, and one liana, a relic of the Tertiary period and endemic of the Eastern Caucasus - Hedera pastuchovii, in the studied areas of beech forests. The seven ephemeroids are among the rare species.

There are 44 endemic species in the flora of the studied areas of beech forests. The history of the development and re-penetration of the beech forests of Dagestan has a great influence on the endemic composition of the flora. Endemic to the Eastern Caucasus are: Hedera pastuchovii, Calycocorsus tuberosus, Scrophularia hyrcana. One species belongs to the endemic species of the Central and Eastern Caucasus 
- Galanthus angustifolius. There are three endemics of the Greater Caucasus - Betula raddeana, Cerastium holosteum, Heracleum sommieri. The remaining 37 species are endemic to the Caucasus. It should be noted that the general tendency of an increase in the percentage of endemism with an increase in height above sea level persists in relation to the beech forests of Dagestan. There are 43 relic species of different periods in the studied areas of beech forests. Most of them belong to the relics of the Tertiary period, and some are "true" species of beech forests in Dagestan.

The data on the assessment of the conservation significance of the associations of beech forests in Dagestan are given in Table 2.

Table 2. Assessment of the conservation value of beech forests associations associations in Dagestan (with addition from Kh.U. Aliev [13])

\begin{tabular}{|c|c|c|c|c|c|c|c|c|c|}
\hline \multirow{8}{*}{ No } & \multicolumn{8}{|c|}{$\begin{array}{c}\text { Criteria } \\
\text { Number of } \\
\text { trial plots }\end{array}$} \\
\cline { 2 - 9 } & $\mathbf{F}$ & $\mathbf{B}$ & $\mathbf{S}$ & $\mathbf{N}$ & $\mathbf{D}$ & $\mathbf{V}$ & $\mathbf{C}$ & $\mathbf{P}$ & \\
\hline \multicolumn{8}{|c|}{ Lowland end Piedmont } \\
\hline $\mathbf{1}$ & 9 & 3 & 2 & 3 & 2 & 2 & 21 & $\mathbf{2}$ & 7 \\
\hline $\mathbf{2}$ & 9 & 3 & 6 & 3 & 2 & 2 & 25 & $\mathbf{3}$ & 2 \\
\hline $\mathbf{3}$ & 9 & 3 & 2 & 3 & 2 & 2 & 21 & $\mathbf{2}$ & 7 \\
\hline $\mathbf{4}$ & 9 & 6 & 6 & 3 & 2 & 2 & 28 & $\mathbf{3}$ & 3 \\
\hline $\mathbf{5}$ & 6 & 3 & 4 & 3 & 2 & 2 & 20 & $\mathbf{2}$ & 3 \\
\hline $\mathbf{6}$ & 6 & 3 & 2 & 3 & 2 & 2 & 18 & $\mathbf{2}$ & 8 \\
\hline $\mathbf{7}$ & 9 & 9 & 8 & 3 & 6 & 2 & 37 & $\mathbf{4}$ & 1 \\
\hline $\mathbf{8}$ & 9 & 6 & 8 & 3 & 6 & 2 & 34 & $\mathbf{4}$ & 1 \\
\hline $\mathbf{9}$ & 6 & 3 & 4 & 3 & 2 & 2 & 20 & $\mathbf{2}$ & 1 \\
\hline $\mathbf{1 0}$ & 9 & 9 & 8 & 3 & 6 & 2 & 37 & $\mathbf{4}$ & 2 \\
\hline $\mathbf{1 1}$ & 9 & 6 & 6 & 3 & 2 & 2 & 28 & $\mathbf{3}$ & 2 \\
\hline $\mathbf{1 2}$ & 9 & 6 & 6 & 3 & 2 & 2 & 28 & $\mathbf{3}$ & 4 \\
\hline \multicolumn{8}{|c|}{ High-montainous } \\
\hline $\mathbf{1 3}$ & 9 & 3 & 4 & 3 & 2 & 0 & 21 & $\mathbf{2}$ & 2 \\
\hline $\mathbf{1 4}$ & 3 & 6 & 4 & 3 & 2 & 0 & 18 & $\mathbf{2}$ & 2 \\
\hline $\mathbf{1 5}$ & 3 & 6 & 6 & 3 & 2 & 0 & 20 & $\mathbf{2}$ & 2 \\
\hline $\mathbf{1 6}$ & 9 & 3 & 8 & 3 & 2 & 0 & 25 & $\mathbf{3}$ & 13 \\
\hline $\mathbf{1 7}$ & 6 & 6 & 6 & 3 & 2 & 0 & 23 & $\mathbf{3}$ & 5 \\
\hline $\mathbf{1 8}$ & 3 & 3 & 4 & 3 & 2 & 0 & 15 & $\mathbf{1}$ & 4 \\
\hline $\mathbf{1 9}$ & 3 & 3 & 4 & 3 & 2 & 0 & 15 & $\mathbf{1}$ & 4 \\
\hline
\end{tabular}

F - floristic significance, B - phytosozological value, S distribution, $\mathrm{N}$ - naturalness, $\mathrm{D}$ - area reduction, $\mathrm{V}$ renewability, $\mathrm{C}$ - protection category, $\mathrm{P}$ - security provision; № - number of association: 1 - Fagetum compositum fruticoso-varioherbosum, 2 - Fagetum compositum lonicerosovarioherbosum, 3 - Fagetum compositum carpinosovarioherbosum, 4 - Fagetum nudum, 5 - Fagetum filicosum, 6 - Fagetum festucosum, 7 - Fagetum taxoso-ilexosum, 8 Fagetum taxoso-varioherbosum, 9 - Fagetum rubosum, 10 Fagetum qercoso-euphorbosum, 11 - Fagetum sambucosoefemeroso-filicosum, 12 - Fagetum efemeroso-varioherbosum, 13 - Fagetum compositum filicoso-varioherbosum, 14 Fagetum compositum varioherbosum, 15 - Fagetum fruticosofilicoso-varioherbosum, 16 - Fagetum filicoso-varioherbosum, 17 - Fagetum myrtilloso-varioherbosum, 18 - Fagetum festucosa-varioherbosum, 19 - Fagetum compositum festucoso-varioherbosum.

It should be noted that the high edificatory role of Fagus orientalis is the main factor in the formation of less species associations. In addition, a distinctive feature is the saturation of all studied plant communities with relict and endemic species. The high conservation value of the associations of beech forests in Dagestan is associated with the history of the formation of beech forests and growth in relatively arid conditions in comparison with other parts of the general area, which influenced the floristic composition.

Of the 19 associations identified by us, the highest conservation value, assessed by us as communities with a high value $-\mathrm{P} 4$, are concentrated in the beech forests of the refugia of the Lowland and Piemont zone. Thus, the association Fagetum taxoso-ilexosum in the study area grows only at one local point, occupying an area of less than 1 ha [19]. This is the only area of the beech forests of Dagestan with evergreen undergrowth, formed by a predominantly vegetative reproduction of a rare species - Ilex hyrcana. In addition to the Ilex hyrcana, Taxus baccata grows in the undergrowth, which is listed in the Red Data Book of the Russian Federation (Fig. 2).

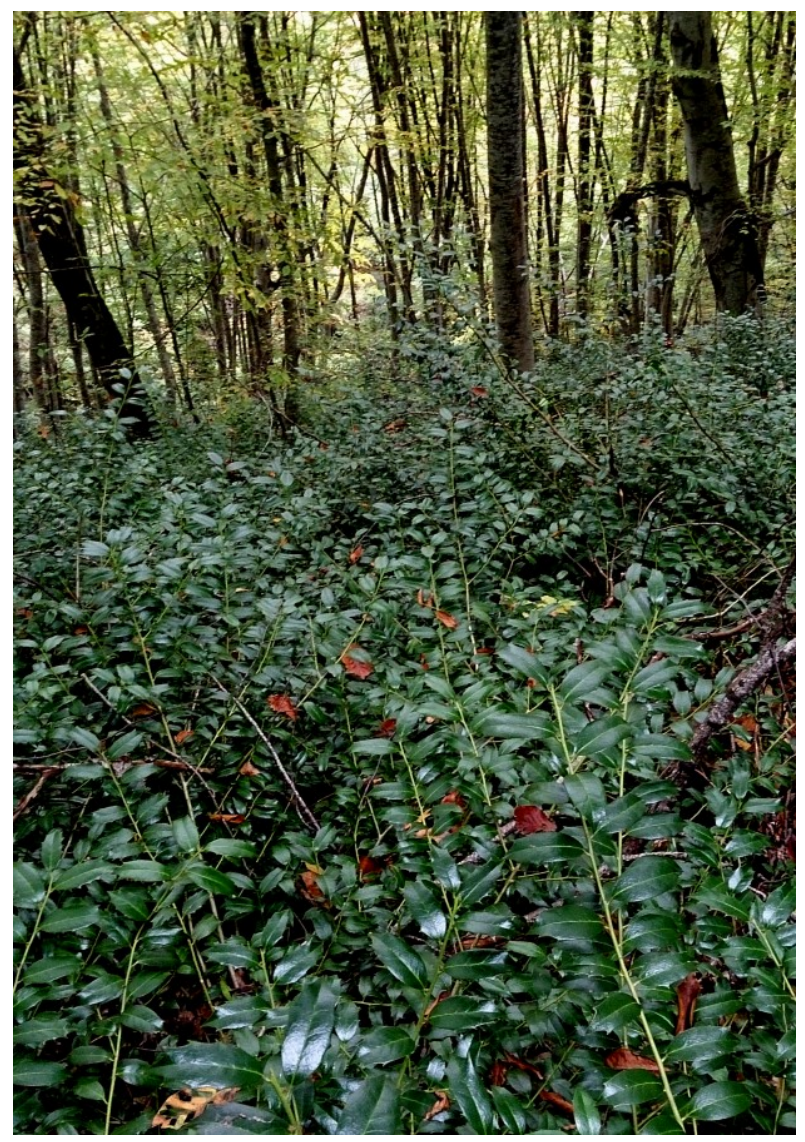

Fig. 2. Ass. Fagetum taxoso-ilexosum, Tabasaran district, near the village of Gurkhun - photo before the fire (2010 year)

The investigated forest area was subjected to the pyrogenic effect of a ground fire in 2017. The association is currently in critical condition. The loss of the Ilex population can occur due to the death of the eastern beech in the tree layer, on which a negative pyrogenic effect is observed at the base of the trunks (Fig. 3). In the close vicinity of the site, a hornbeambeech forest grows, where we noted the growth of such protected species of the Red Data Book of the Russian 
Federation as Allium paradoxum and Galanthus lagodechianus, as well as a large number of relics and endemics. Considering all of the above, it is necessary to take measures to include it in the PA system at the regional level in the investigated area. This site in the Russian Federation is the only one where Ilex hyrcana grows.

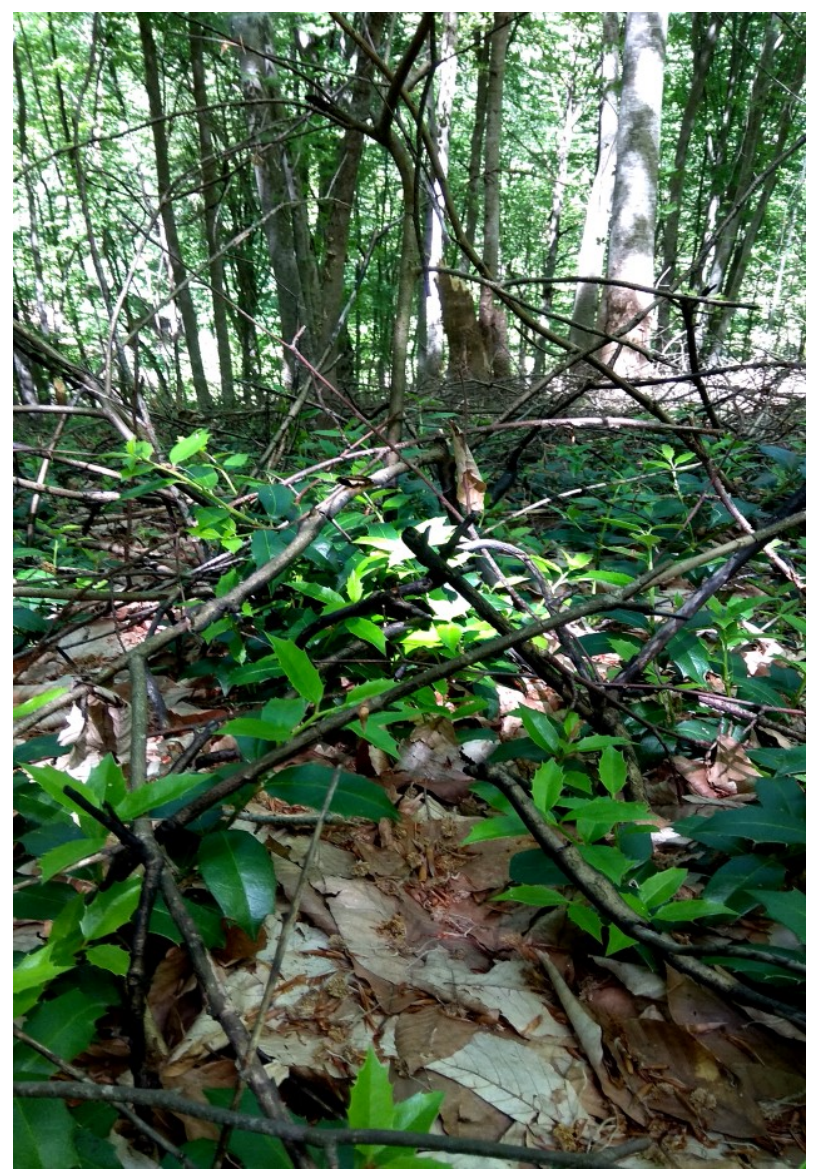

Fig. 3. Ass. Fagetum taxoso-ilexosum, Tabasaran district, near the village of Gurkhun - photo after the fire (2018 year)

Occupying small areas, we have isolated the association Fagetum taxoso-varioherbosum practically over the entire broken strip of beech forests in Piedmont Dagestan (Fig. 4). In addition to Taxus baccata, Allium paradoxum is a rare species of Federal importance. From endemics and relics grow: Pachyphragma macrophyllum, Polygonatum glaberrimum and the edificatory itself - Fagus orientalis. It should be noted that such plant communities are found in ecotopes where a prerequisite is the presence of a direct outcrop of parent limestone rocks with soil moisture, since Taxus baccata is a calcephile and does not tolerate acidic soils.

The association Fagetum qercoso-euphorbosum, described by us in Lowland Dagestan in the Samur liana forest, occupies insignificant areas and is protected in the Samur National Park (Fig. 5). The investigated area of the beech forest must be included in the protected use regime, as a particularly valuable forest area. It is home to such federally protected species as Crocus speciosus, Hedera pastuchovii, Allium paradoxum and regionally protected vines - Clematis vitalba and Smilax excelsa.

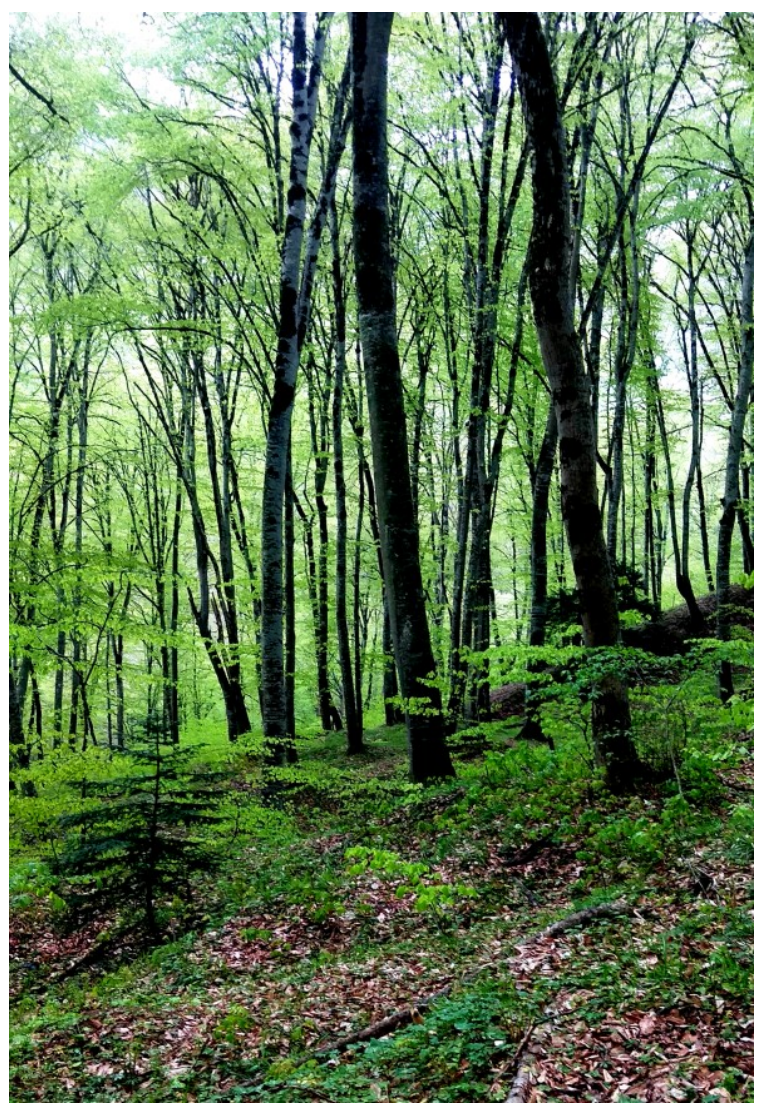

Fig. 4. Ass. Fagetum taxoso-varioherbosum, Kaitagsky district, near the village of Karatsan

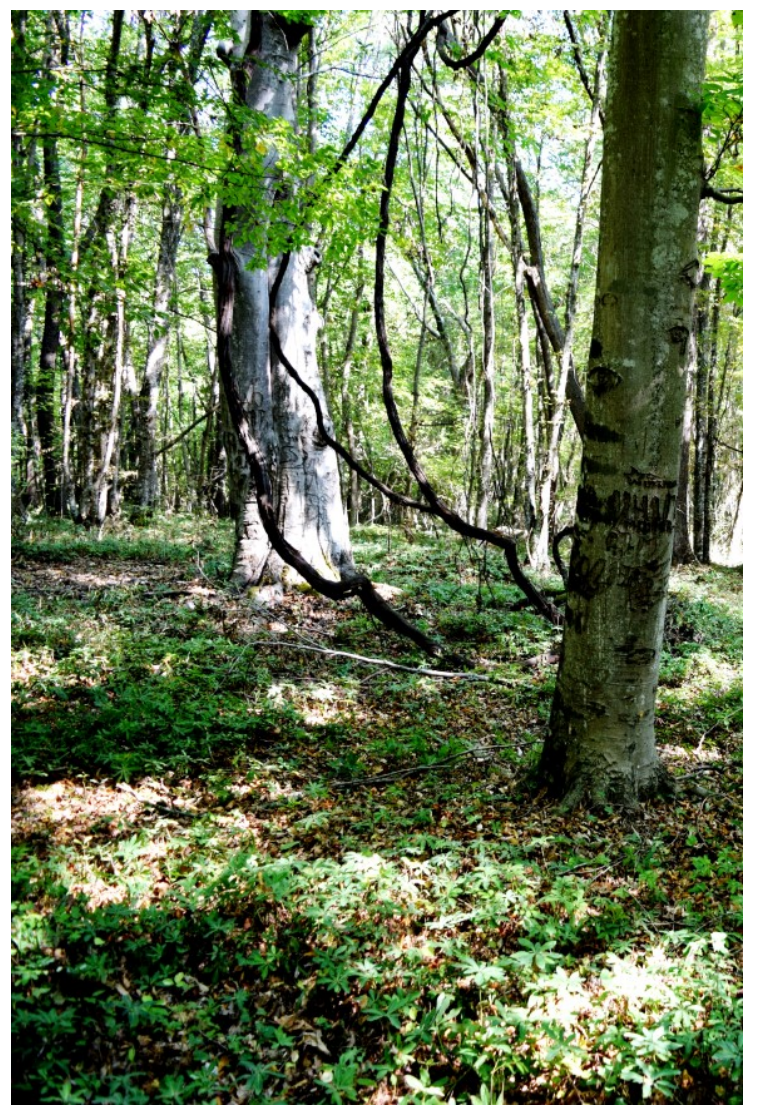

Fig. 5. Ass. Fagetum qercoso-euphorbosum, Magaramkent district, near the village of Primorskoe 
The conservation significance of such associations of foothill beech forests as Fagetum nudum, Fagetum compositum loniceroso-varioherbosum, Fagetum sambucoso-efemeroso-filicosum, Fagetum efemerosovarioherbosum have a high score (P3). They occupy a relatively small area. Each trial plot contains 1-2 protected species of the Red Data Book of the Russian Federation and the Red Data Book of the Republic of Dagestan. In addition, they are rich in relict and endemic species.

The associations Fagetum compositum fruticosovarioherbosum, Fagetum compositum carpinosovarioherbosum, Fagetum filicosum, Fagetum festucosum, Fagetum rubosum occupy the largest areas in the beech forests of Piedmont Dagestan. We assessed them as communities with an average conservation value - P2. They include the growth of at least 1-2 species listed in the Red Data Book of the Republic of Dagestan, and a significant number of relict and endemic species.

All associations of beech forests in Piedmont Dagestan are subject to a reduction in areas under the influence of a high anthropogenic load: felling, cattle grazing, and economic development of the territory. Most of the territory where beech forests grow in Piedmont Dagestan is not part of the protected area.

In High-mountain Dagestan, the seven associations identified as part of subalpine beech forests occupy small areas, growing among mixed pine and birch forests. The highest conservation value (P3) is represented by the associations of Fagetum filicosovarioherbosum, where such rare species as: Fritillaria lagodechiana, Woodsia fragilis and Lilium monadelphum (Fig. 6), and Fagetum myrtillosovarioherbosum (Fig. 7), with such species as Vaccinium arctostaphylos, Epipogium aphyllum, and Dactylorhyza urvilleana. Just like all associations, the studied communities are distinguished by the growth in them of a large number of relict and endemic species.

We assigned the associations Fagetum fruticosofilicoso-varioherbosum, Fagetum compositum varioherbosum, and Fagetum compositum filicosovarioherbosum to communities with an average conservation value (P2). On the majority of the sample plots described, 1 protected species listed in the Red Data Book of the Russian Federation and 1-2 rare species of the regional level are found. Also, all associations are rich in relics and endemic species.

The associations Fagetum festucosa-varioherbosum and Fagetum compositum festucoso-vatioherbosum were classified by us as communities of low conservation significance $-\mathrm{P} 1$. There are 1-2 rare species of the regional level, relict and endemic species.

In the identified associations of High-mountain Dagestan, no reduction in areas is observed. As noted above, there is a process of replacement of primary mixed pine and birch forests with beech forests. The second reason for the lack of area reduction, in contrast to the Piedmont zone, is associated with the inaccessibility of areas of beech forests for felling and export of valuable timber and the inclusion of the studied areas in the territory of the Bezhtinsky and
Tlyaratinsky sanctuaries.

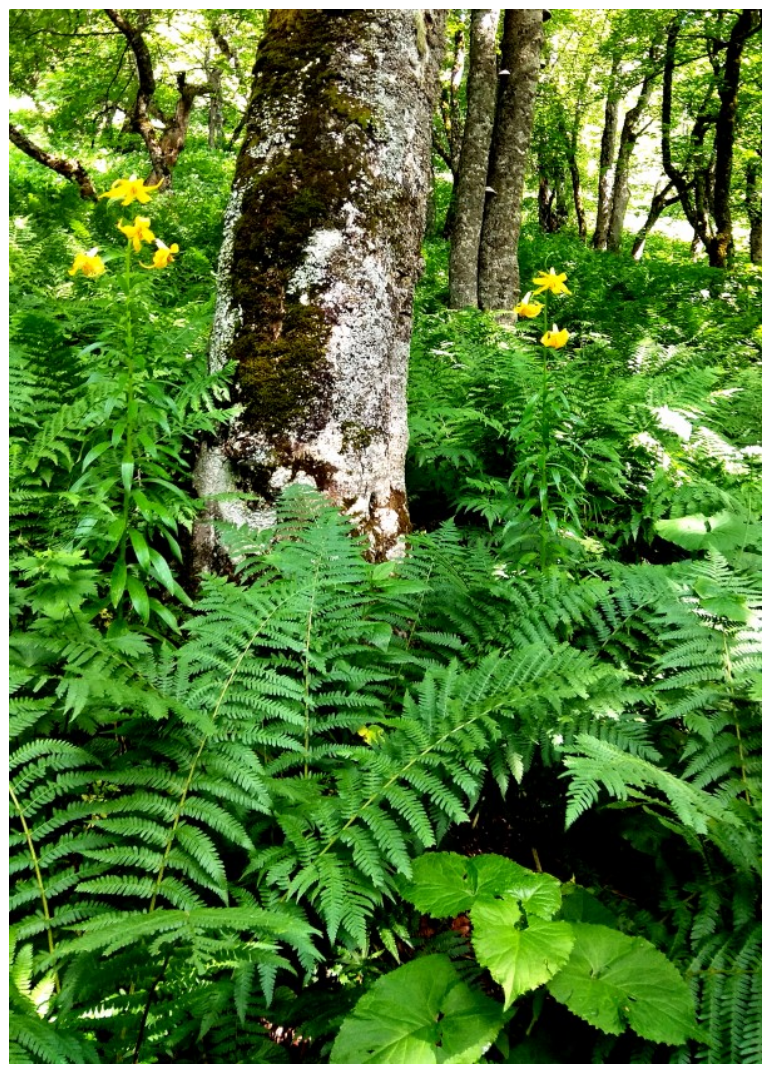

Fig. 6. Ass. Fagetum filicoso-varioherbosum, Tsuntinsky district, near the Mushak pass

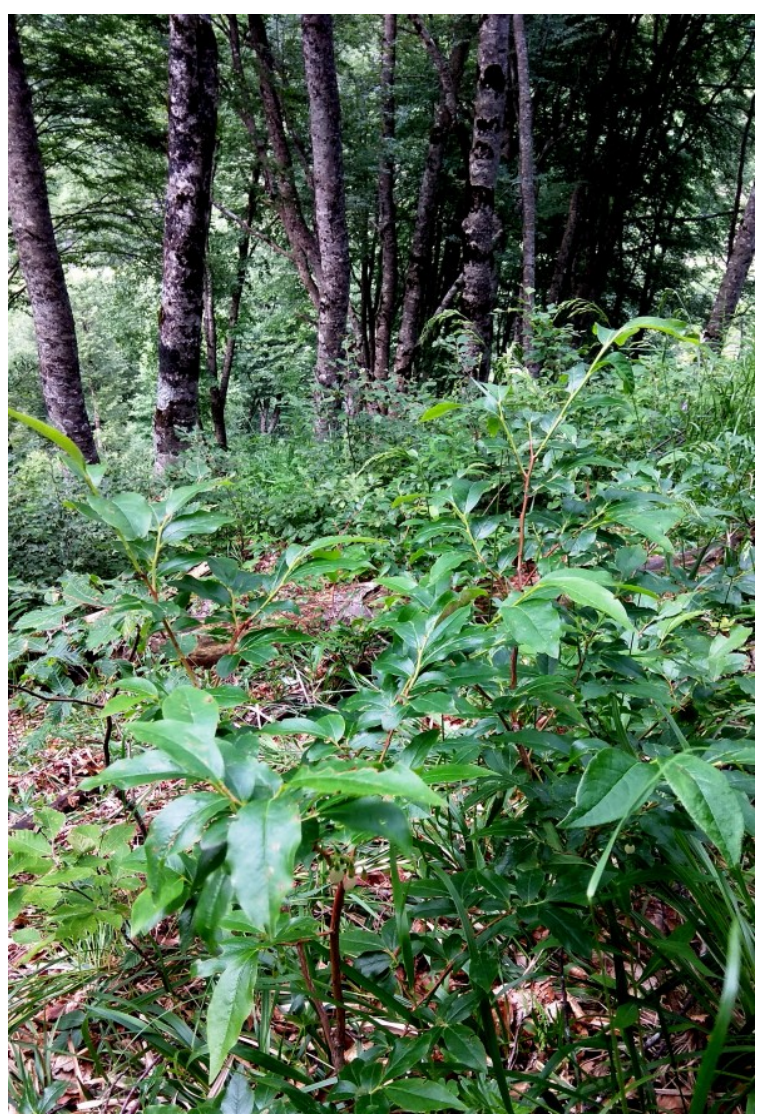

Fig. 7. Ass. Fagetum myrtilloso-varioherbosum, Tsuntinsky district, near the Mushak pass 
From the above, it can be seen that beech forests are of high conservation value for the preservation of valuable species of higher vascular plants of the flora of Dagestan. In this work, we do not provide information on a significant number of protected species of mosses, lichens, and fungi that grow only in the beech forests of Dagestan, which makes them even more valuable [14]. In recent years, the situation has worsened with an increase every year in the foci of forest fires associated with global warming. In this regard, we propose the allocation in Piedmont Dagestan of at least three intact forest areas of beech forests, each with an area of at least 2500 hectares, for inclusion in the PA system, in agreement with the Forestry Agency of the Republic of Dagestan and the Ministry of Natural Resources and Ecology of the Republic of Dagestan.

\section{References}

1. V.B. Martynenko, B.M. Mirkin, E.Z. Baisheva, A.A. Muldashev, L.G. Naumova, P.S. Shirokikh, S.M. Yamalov, Adv. Environ. Biol. 135, 10 (2015).

2. Yu.L. Menitskiy, Synopsis of the flora of the Caucasus. Fagus. 3, 2 (2012).

3. M.P. Maltsev, Beech. (1980).

4. P.L. Lviv, Forests of Dagestan. (1964).

5. Kh.U. Aliev, Botanical Herald of the North Caucasus. 4 (2019).

6. I.I. Tumadzhanov, Proceedings of the Tbilisi Botanical Institute. 7 (1939).

7. I.I. Tumadzhanov, History of the Holocene (1961)

8. I.I. Tumadzhanov, Bot. Zhurn. 9, 56 (1971).

9. P.L. Livov, Collection of scientific reports of the Dagestan branch of the All-Union Botanical Society (1970).

10. P.L. Livov, Bot. Zhurn. On the spread of beech forests in Dagestan. 55, 9 (1970).

11. Kh.U. Aliev, A.M. Koltunova, M.G. Kutsev, B.S. Tuniyev, Turczaninowia. 23, 4 (2020).

12. Yu.N. Neshataev. Methods of analysis of geobotanical materials (1987).

13. Kh.U. Aliev. Botanical Herald of the North Caucasus. 2 (2020).

14. Red book of the Republic of Dagestan. 800 (2020).

15. R.A. Murtazaliyev, Kh.U. Aliev. Bot. Zhurn. 93, 11 (2008).

16. Kh.U. Aliev, R.A. Murtazaliev Proceedings of DSPU. Natural and exact Sciences. 2, 11 (2010).

17. Kh.U. Aliev. Biological diversity of the Caucasus: proceedings of the XII International scientific conference (2010).

18. Kh.U. Aliev. Regularities of distribution, reproduction and adaptation of plants and animals: materials of the all-Russian conference (2010).
19. B.A. Abakarova, Kh.U. Aliev. Environmental significance of Botanical gardens: proceedings of the International conference (2010). 